\title{
Priesthood and ecclesiology
}

\author{
PhD. Mihai Sebastian STOIAN \\ $\mathrm{PhD}$. in the theological studies from Ovidius \\ University of Constanta \\ ROMANIA \\ E-mail: stoian.mihai55@yahoo.com
}

\begin{abstract}
Reason for being, the significance of the ecclesial ordained ministry, cannot be understood but starting from the Church itself and from the dependency link, from the charismatic-historical life and present at the same time - of Christ who constituted and defined. Starting from this link of the Church with Christ, which is the Body link with His Head through which pours the Spirit life in the whole body, we understand why it exists and must be this ordained, original, «main» or "fundamental» ministry. Starting from here, can be understood, to what extent it is absolutely necessary for preserving the Church's vocation and its mission and how it is possible to affirm that he belongs to its essential structure, in a word as it is deeply ecclesiastic.
\end{abstract}

Keywords: ecclesiastic, church, signum, convergence, ministry.

\section{Introduction}

Priesthood and ecclesiastic are two notions and two realities involved in Christ through the Holy Spirit who constitute the Church in its quality of the body of humans or the sacramental community with God through Christ. The fundamental charismaticstructure or charismatic-sacramental of the Church not only does not exclude, but on the contrary includes and involves with necessity the ordained ministries instituted by Christ and consecrated by the power of the Holy Spirit in the sacrament of the Autocephalous Orthodox Churches. The ordained ministries and the charismatic ministries are against their wills: they have no objection, they would oppose only if the gift received from God would not be seen, if all good and bad and this would exclude any intervention by the community towards Him. A charisma is given forever for a task, for a Ministry, for a function to be carried out and for the Church and referred to the functions (deaconry, testimony and fellowship), which reaches the mystery of the Church: on their own, any charisma is functional. [1] And vice versa, there are tasks or functions in the Church which does not sit on a charisma that make them possible and invest them. The double reference to grace or gift of the Holy Spirit and the Christian community for which they are given, and even these are given, is always present; but this can operate in different ways. Forever the charisma or grace received, qualify and make the receiver able to serve, but the role of the community can take different forms.

\section{The ordained ministries}

The ordained ministries are based on charisma or more specifically on the grace of the ordination, in one of the three steps of the priesthood, given once and for all, permanent, and whatever the originality and function of the ordained ministry, whatever its role as essential and irreducible to all others, the Ministry, is a charisma by all the others, but not outside the Church, or without reference to the Church. 
Going over the complex issue of the biblical vocabulary for the first two centuries of the early Church, expressing these ministries, being primarily a matter of exegesis, taking as a basis to develop the ecclesiastic priesthood, the fact that the expression of «ordained ministry» contains the bishop and the presbyter, i.e. the priest first, and then all three steps of the chary ministry: the bishop, the priest and the deacon. Non-distinguishing between bishops and priests (presbyters) giving testimony about the New Testament might ensure very well, stresses Professor J. Hoffmann, to retrieve a meaning, allowing you to see in the Bishop, the essential and fundamental function and lie the Presbyterian (priesthood) in the episcopacy line, whose function he imparts to his level: essentially a function of «presidency», i.e. responsibility in relation to the vitality and unity of the Christian communities, as well as with their fidelity towards the apostolic testimony[2].

The Church is related to the event of the Jesus Christ from which it pulls the existence and reason of being: it may not be as sacrament of salvation in the midst of people than by its dependence on Christ with the power of the spirit, which is in it from the Pentecost. The Ministry of Christ finds the source and norm of its own ministry, and the multiple ministries that this express, but which are the work of the Holy Spirit, given in the edification of the Church as the body of Christ (Ephesians IV, 12). "The Church does not exist and cannot accomplish its mission than being summoned, added from another: Christ, upon which it depends in some way radically and in all the works." [3]

The Catholic Doctrine press on heavily this total and unilateral dependence to the Church towards Christ and speaks very little of its connection with the Spirit, as if Christ is conceived without His Spirit. Defining this dependency upon Christ, Professor J. Hoffmann specifies: "This addiction is double: on one side of the Church is founded in the work that God had fulfilled "at that time" and "once and for all" through the historic mission, death and resurrection of Jesus and the gift of the Spirit, of the other part, it depends on the permanent action of the Risen Christ, Lord of the Church and the world. And there is no Church there, after His truth and cannot determine its mission with these two conditions: a) to recognize the kingship of Christ, confessing that she has no other identity than that which she has received from an initiative that it prevents that receives in the Spirit, and b) to openly acknowledge the One conceded that she confesses as Christ, as Jesus of Nazareth and that she lives in fidelity to the Gospel." [4]

\section{2. "The seal" of Christ}

It is essential and positive to note that these developments significance toward the Church's dependence on Christ, but Christ who does not necessarily has the Spirit with him. Continuing his reasoning behind this dependency, he says: This double relationship of the Church with the One, and the only Mister who marks the Being of the Church, cannot be ensured unless it is mediated — «médiatisée» - for signs, signed up specifically in the structure of the Church and to decipher the faithful, stating that the Church does not belong to the Church which must bear in his body as a visible sign of the seal, the sign of its current dependence in relation to the initiative of establishing Christ, gathering ceaselessly His Church, and his fidelity towards the Gospel of Jesus at the same time." It is loss of sight, however, one very important thing: the ordained Ministry is not only a signum of Christ, which marks the Church's dependence on Christ, is a signum of Christ full of the Holy Spirit and explicit language, a servant of Christ as steward of the Mysteries of God (I Cor. IV, 1). For it is Christ who is present in the Church and works through his spirit. This signum is first, immediately after the Ascension of Christ, to the father in order 
to praise, to that of the Apostles present in the Christian communities or those who are present through occupation or serving to represent them or to keep ties with them: the bishops. The founder of the Church of Christ is and remains only the one that introduces in history as, the Catholic sacramental community, in the Spirit of Pentecost. The Apostles are sent by Christ to announce God's work of salvation of the world, through life, sacrifice on the cross and resurrection of Christ and to manifest concretely through their presence of sent, that the Church is founded upon Christ and to keep its initiative mission in the world. "Receiving the Gospel does not take place without recognition of the Apostles' mission; receiving and referring to their Ministry maintained the funds sent by the Christ, expressed, on behalf of the communities, therefore, the confession that they draw their origins not from themselves, but from the origin of Another on sending the Apostles attests and means it. As the Apostolic generation disappeared, the martyrs and original envoys and their disciples - and the distance between the establishing event and the current life of the churches is growing the Apostles' time, increases and is awarded and appreciated as a reference. The Christian communities should not ever stop to be able to build on this foundation which is the Apostles should remain faithful to their testimony." [5]

The apostolic ministry of bishops and then, the followers of the Apostles, is understood in the newer version of the Western theology as a signum that keeps the Church linked to Christ and constantly referring to Christ. And the version ordained by the ordained ministry position with Christ and reporting to the community that by affirming the ministries are working in persona Christi. But this means a substitution of Christ himself. The recent theologians seek to accredit a broader ecclesial explanation to this in persona Christi, saying among other things: “It is not about having the ordained ministry as ,another Christ" (sacerdos alter Christus), to consider that "His representative" or another "mediator", but to express that this Ministry is actually in Christ's ministry to the community, and this in a doubt: on the one hand the Ministry must fall into the version of Christ and His Gospel; but, on the other hand, he is to serve Christ as the instrument and a "sign" for community. The ministry "is not" Christ in the version in which this is to be present as "a ministry version", but the ministry's work for the community send this to Christ current work from which the Church is coming. But in Mgr. R. Bouchez' Report, in the Plenary French Episcopes Assembly, Lourdes, 1973, it is stated: "The priests and the bishops are the servants and signs for Christ's ministry, for the people of the New Alliance. They are not Christ. They do not take His place. Moreover, they do not take place of the other Christians and their own servants. They are the servants of Christ for allowing the other Christians to live the truth and reality of their vocations and service.'[6]

The Ministry is not independent to the community neither outside it nor does claiming engrossment of a responsibility that belongs to everyone. But he "is not a reflex of the community, but his presence and work signifies what Christ gives to be and become the spirit whom he depicted it." And ending argumentation the: "therefore, the ordained Ministry work «in persona Christi» do not have ever considered independently of his work «in persona Ecclesiae». For "the Ministry cannot work in persona Christi only in so far as he himself is a disciple of Christ and a member of this community, that he «represents» ... «And vice versa: If the community recognizes in the Ministry work because he presents the Gospel of Christ, it cannot yet identify itself as Church of Christ, only to the extent that it recognizes this Ministry as working for it in persona Christi”. And with this explanation, the ordained Ministry's position remains a position vis-à-vis the community. The one linking the Church to Christ, after the orthodox doctrine, is the Holy Spirit given to it on the 
day of Pentecost and which remain permanently in it. He works through all the members of the body of Christ. And if the Bishop represents or expresses the Church and is an iconic presence of Christ in it, this is due to the spirit of Christ given to Bishops by the mystery of the Autocephalous Orthodox Churches, to work in the Church and together with His Church.

In the priest, in the Bishop and in the episcopate is represented in a manner recognized by all, i.e., «the official» Church community (the Parish, the diocese, the Church entirely)." The priest and the Bishop represent the whole community, but not broken by the community, but as a kind of head that has in self-organic connecting with community. He is the spokesman of what lives the entire body and what he himself lives in the body, along with the body. It is seen first in prayer, invocation of the Holy Spirit and in the bringing of sacrifice and in the fact that through these sacrifices of their descending grace, the Mysteries in the Church, in the faithful, it is committed the Eucharistic sacrifice, in order to give the Church and the faithful with all the benefits connected with it." [7]

The Apostle Paul, "sending of Miletus to Ephesus, called to him the priests of the Church" (Acts 20,17). "This expression, "tous presbitërous tes ekklesias", is very characteristic: well-worn houses (priests) are forever linked to a local community, here, that of Ephesus; never in the course of the first century, was this term used to denote an itinerant Ministry. [8] The priest and the Bishop are linked to a specific community (parish or diocese), belonging to them, they identify with them. In their papers, they do not supersede the community, they do not commit these acts «in the name of» the community, but together with it, they do not embody the community in themselves. At mass, the priest says: "he that we have given these new public prayers and pray together and at two and three unite into Your name, you promised to fulfil the requests of them, and now embody the useful requests of Thy servants" (Antiphon, Prayer III at Mass).

The priest is one who says aloud the prayer of those gathered "in the name of Christ" and in the Church: "God, our God receive this earnest prayer of thy servants, and have mercy on us... and send your mercies on us and on all your people...." [9] and all he asks for them all, saying: "O Lord, Father of mercies ... those who bowed their heads to you, bless them, sanctify them, guard them, strengthen them, give them their power... and dignify them, without condemnation to share with those of your immaculate and lifecreating Mysteries...." [10] This is because it has been put to it: "O Lord our God, we have built us and brought us into this life.... You are the one who put us in this ministry with the power of Your Holy Spirit. Be pleased, O Lord, to be servants of Thy New Law, performers of the Holy Mysteries.... "And once brought the Eucharistic sacrifice, the priesthood power of the same grace that was given by the Spirit of Christ, the priest asks: "Give ear, Oh, Lord, Jesus Christ, our Lord, in thy holy place ... and come to us ... and we consecrate ourselves unworthy by a mighty hand, to be given Your New Immaculate Body and Your Precious Blood and through us to all the people." [11] While praying with the community or draw it in his prayer, however, the word of the priest includes and is present throughout the community feeling and praying together with him.

The presence and location of the Bishop in the Church are related to the Eucharist, but he is not alone, but surrounded by priests and deacons: "You take care not to participate but to one Eucharist, because there is only one body of our Lord Jesus Christ and a single chalice to unite us with his blood, one altar, as one Bishop with the presbytery (the priests) and deacons... so all what you will do you will make after God." [12] And the relationship 
with the members of the Church Bishop is that of coverage through love itself to them, after the example of Christ, the Head of the Church, the unseen Archpriest. [13]

\section{The convergence of the ecclesial community}

The community lives, it relates to what it says and does the Bishop or the priest, it appropriates what he does; her voice is in prayer alongside that of the Bishop or the priest, but it is not the first voice, that representative. The faithful feel the need to overcome their own subjectivity in their requests to God. That is why they appeal to the priest's prayer and assigns their subjectivity to the priest's words, but associate their interest in the subjective words and acts of the priest who are not biased, because they are not up for it in the first place, but for those who asked him to pray and invoke the grace of the Holy Spirit. Of course, the priest prays for him, but still, bestowing to bring the bloodless sacrifice, the Eucharist, with the power of the Holy Spirit, on it that is «clothed in the grace of the priesthood» [14], to be reinforced towards one or another job from the mysteries of the Church [15], to make it descend the grace of the Holy Spirit upon those who run to Christ in his Church. Without a bishop and without Church priests there, because the faithful cannot get themselves their own subjectivity [16]. This is one of the reasons for which St. Cyprian says: "If somebody is not with the bishop, he is not in the church".

In the Bishop, the priest converges as the ecclesial community converges in him who has the leadership, the life and the movement of any body. And this not only in terms of the Eucharist and Eucharistic sacrifice, due to bringing in the highest degree, it is true, but also in terms of the proclamation of the Gospel, that is to say of the liturgy of the word, which reaches its climax and it makes the Eucharist. The subjectivity of the believers in terms of diversity faith is outdate and needs to be overcome, because not any faith saves, but only the right and sound, through what they learn through the bishops and priests themselves.

The Apostles and those who followed them, invested with the power of the spirit in the sacrament of the Autocephalous Orthodox Churches, Christ has entrusted the power and commandment to teach His Gospel with the sanctification and salvation of their leadership in the Church, assuring them that he would always be with them (Matt. 28, 18-20) and that those who will believe them and will share with the grace of the spirit through the Sacraments of the Church committed by them, in the Church, will be saved (Mark 16, 16). So the convergence of the ecclesial community, the Bishop must be total, as everything must be total and the convergence of the Bishop in the Church should be, indeed, and he has an iconic presence of Christ in His Church.

And because the Church lives unitary, through invoking God by bishops and priests through the responses to them from God, "God's goodwill must be with those who submit to Him these invocations, as they enjoy the accomplishment on his part, i.e. they must be recognized by God as community representatives. This goodwill is a special grace, granted at the request of the Church, after their submission to God, of course through them that do this invocation of God's grace in behalf of the Church and along with it." [17] and if any 
worthiness to obtain from God, but as a gift of the spirit, and if anything the wolves prayer and personal fulfilment is the fruit of a gift of the spirit, the more prayers for the community feelings can't be gracious than fruit or a special gift he received for the community that converges in him and as well as personal prayers, life and personal actions are reinvigorate and enhanced by the grace received through the mysteries of the Church, the more prayers and gifts received by someone in the community, must be reinvigorate of a Sacrament grace, i.e. for the community of Autocephalous Orthodox Churches.

The Ministry of the Bishop and the Priest can be defined as a ministry of «presidency», but stating that he always remains within the ecclesial community, bound by it and along with its faithful subjectivities transcending precisely because of the grace of the spirit given to him, in this sense, the mystery of the Autocephalous Orthodox Churches. "A 'presidency' ministry, noted Prof. J. Hoffmann, does not want to deploy ministry trilogy tasks... or to redact the pastoral Ministry of the community, the Ministry of the Word and of the Mysteries, but emitted a fundamental function of enabling the integration of these tasks in a consistent manner". "This presidency is, indeed, a paradoxical presidency: it involves a real authority exercised in the name of Christ, in order to the Church edification, but the nature and legitimacy of its indisputably precise from serving to ensure stewardship action of God in Christ for the benefit of the people. The Ministry cannot exercise its authority only to the extent that he is the servant of Christ and his Gospel; at the same time because this Gospel is a Gospel of grace and freedom, this authority is not genuine unless it is recognized and received as a sign of Christ, the only Shepherd of the Church, and if it is fulfilled in respect of the freedom of the spirit who works in the community." [18]

But this definition of the ordained ministry presidency is under the Catholic articulated doctrine only in Christ and in Christ separated from Spirit and Himself sufficient. It is a presidency which does not express the communion and does not call to communion with God on those assembled, is a top presidency imposed exclusively, has not the convergence and unity at the same time. The Bishop and the priest work as authoritative works in persona Christi - hence the lack of the general epiclesis who has a deep character. All the developments brought about by the Plenary Assembly of the French Episcopate (Lourdes, 1973) to this notion of presidency, regarded as expressing in the most proper way the being and the work of the ordained ministry, remain only in the appearance of authority. [19]

\section{Conclusions}

Defining the ordained ministry as «ministère de présidence» lacks the pneumatological ecclesial dimension of the own orthodoxy. "The Church conceived as a living organism, held in unity by the Holy Spirit, understood as an interpersonal relationship in the Church, as a personnel fluid that flowed from the head of the Church of Christ, binds the members and the head and makes it impossible to design the exercise of the functions, to any but in Church outside the relationship with the whole ecclesial community. Those who practice the Mysteries in the Church, commit them in the relationship with the community, to which are bound by the Holy Spirit. The Holy Spirit conceived as a 
relationship between all believers and all ministries, makes it impossible the individualism on general scale or the hierarchical exclusiveness, it is impossible the thesis of an infallibility "ex sese non ex consensu Ecclesiae". No believer is by himself in the Church, because that is not an exercise in isolation, but a gift", and thus no bishop or priest. And hence the natural conclusion: "There is not visible in the Church any Body of the Lord, in addition to any head above the head of the Body, which is Christ. Another head of the Church, but Christ, would make it an autonomous body of Christ, the whole in itself. The admission to the head of the Church of Christ also designed as substituting Christ and would mean that this head be removed from under the interaction of bones, only to be regarded as giving the Body of Christ Himself and not receiving anything of it. And this situation is claimed on behalf of the Pope, when he is assigned the infallibility "ex sese non ex consensu Ecclesiae". But this is merely impossibility. This means to rise a man to the step of the Divinity, with the sense of identification with Christ or rather a doubling of Christ." [20]

The rapport between the preaching of God's word and of the sacred Orthodox Church work can be fully understood only in the light of the Divine Liturgy, which constitutes the essence of thinking and experiencing the Orthodox spirituality.

\section{REFERENCES}

[1] Rev. Prof. Dumitru Radu, "Caracterul ecleziologic al Sfintelor Taine şi problema comuniunii” (The ecclesiastical character of the Sacraments and the communion problem), in: Orthodoxy, year XXX, No. 12, January-June, Bucharest, 1978, p. 322.

[2] Abbe J. Hoffman, Le ministere ordonne dans la communaute chretienne, Strasbourg, 1977, p. 18

[3] Ibid, p. 323.

[4] Ibid.

[5] Ibid, p. 324.

[6] Rapport de Mgr Bouchex, Le ministere des pretes dans L'Eglise tout entiere „ministerielle”, p. 22, apud J. Hoffman, op.cit., p. 31.

[7] Rev. Prof. D. Staniloae, "Din aspectul sacramental al Bisericii" (From the sacramental aspect of the Church), in: Studii Teologice (Theological studies), Year XVIII, 1966, No. 9-10, p. 554. s

[8] Andre Lemaire, Les ministeres aux origins de L'Eglise, Paris, Les Editions du Cerf, 1971, p. 67.

[9] Liturgy of St. John Chrysostom and the Liturgy of St. Basil the Great, The persevering prayer request, immediately after Holy Gospel recitation.

[10] The Liturgy of St. Basil the Great, The consequent prayer after Lord Prayer, uttered in secret by the priest.

[11] Ibid, Prayer before partaking of the priest.

[12] Hieromartyr Ignatius the Godbearer, Epistle to the Philadelphians, IV, pp. $88-89$.

[13] Idem, Epistle to Magnesians, III, 2, p. 63.

[14] Liturgy of St. John Chrysostom, Prayer during the Cherubic Hymn.

[15] Cf. the ordinance of the sacrament of baptism. Prayer after great Litany uttered in secret.

[16] Rev. Prof. D. Staniloae, "From the sacramental aspect of the Church", p. 555.

[17] Ibid.

[18] Abbe J. Hoffman, Le ministere ordonne dans la communaute chretienne, Strasbourg, 1977, p. 34

[19] Rev. Prof. D. Radu, op.cit., p. 330

[20]Rev. Prof. D. Staniloae, Sfântul Duh şi sobornicitatea Bisericii (Holy Spirit and the catholicity of the Church), in: Orthodoxy, Bucharest, year XIX, 1967, No. 1, p. 47. 